\title{
AN ENNOVATING PRECISION SOWING UNIT FOR TRAY NURSERY
}

\author{
Tarek H. A. Mohamed"; Hossam M. T. EL-Ghobashy; \\ Adel A. M. EL-Ashker * ; Ahmed R.Hamed.
}

\begin{abstract}
\end{abstract}
A portable compact precision plug tray vegetable seeder was manufactured in Agricultural Engineering Research Institute (AEnRI) workshop to plant fine and large vegetable seeds with low cost and high seed singulation ratio. The seeder was depended on a controlled negative and positive pressure passed through a set of nozzles to pick up and drop the seeds into the tray cells. For tomato seeds, four nozzles holders equipped with 209 nozzles with inner diameters of $(0.47 \mathrm{~mm}, 0.62 \mathrm{~mm}$, $0.76 \mathrm{~mm}$ and $1 \mathrm{~mm}$ for each set) were tested with negative pressure of (1, 1.25, 1.5 and $1.75 \mathrm{kPa}$ ). For cantaloupe-melon, four nozzles holders equipped with 84 nozzles with inner diameters of $(0.76 \mathrm{~mm}, 1.00 \mathrm{~mm}, 1.2$ $\mathrm{mm}$ and $1.4 \mathrm{~mm})$ were tested with negative pressure of $(6,7,8$ and 9 $k P a)$. The performance of the seeder was evaluated using seed singulation efficiency, seeding efficiency, seeder productivity, specific energy requirement and seeding cost. The machine succeeded to plant large and small seeds in different types of plug trays. The optimum nozzle diameter for planting tomato seeds was $0.62 \mathrm{~mm}$ operated at negative pressure of $1.25 \mathrm{kPa}$ that gave percentage of single seed $89.95 \%$, double seeds $4.79 \%$, multiply seeds $2.39 \%$ and missed seeds $2.87 \%$. Meanwhile, the optimum nozzle diameter for planting the cantaloupe-melon seeds was $1.20 \mathrm{~mm}$ operated at negative pressure $8.0 \mathrm{kPa}$ that gave percentage of single seed $94.05 \%$, double seeds $2.38 \%$, multiple seeds $2.38 \%$ and missed seeds $1.19 \%$. The productivity of precision vacuum trays seeder was 320 tray/ h (66880 and 26880 cells/ $h$ ) for tomato and cantaloupemelon seeds respectively. The total power requirement for the seeder was $1.075 \mathrm{~kW}$.h for tomato seeds and $1.216 \mathrm{~kW}$.h for cantaloupe melon seeds. The consumed specific energy was $\left(3.36 \times 10^{-3} \mathrm{kWh} /\right.$ tray) for tomato seeds and $\left(3.80 \times 10^{-3} \mathrm{kWh} /\right.$ tray) for cantaloupe melon seeds.

*Researcher, Agric. Eng. Research Institute (AEnRI), Dokki, Giza, Egypt. 
The total operating cost was $43.37 \mathrm{LE} / \mathrm{h}$. The cost of one tray seeded by the machine was $0.14 \mathrm{LE} /$ tray comparing with $(0.67$ and 1.67$) \mathrm{LE} /$ try for hand seeding of (cantaloupe melon tray and tomato tray) respectively. The total fabrication cost of the seeding machine was 15000 LE with 2016 price level. The rental value of mechanical seeding per tray was 0.20 LE. The seeding machine indicated net present value (NPV) of 2930 $\mathrm{LE}$ at $11 \%$ interest rate. The seeding machine payback period was about 1.3 year.

Keywords: plug tray, precision plug seeder

\section{INTRODUCTION}

Tn Egypt, vegetable seedlings become one of new agricultural business. Most of the nursery growers use specified expensive hybrid vegetable seeds from first generation. Increasing the demand of vegetable seedlings encouraged nursery growers to use foamy plug trays in seeding, handling and trading. Most common foamy plug trays have been sowed manually. Manual hand sowing for small vegetable seeds in plug trays is very slow, not accrued, and needs high operating cost. Usually, nursery growers use two types of foamy plug tray (84 cells for Cucurbits family such as cantaloupe-melon) and (209 cells for Solanaceae family such as tomato and green pepper). Precision planting of plug trays requires single seed for each cell. Singulation of seeds has been investigated extensively by researchers all over the world and a large number of precision seeding systems with design variations have been developed for different crops. Hanacek and Bickel, 1984 devised a singulating seeder for high-density plug trays, capable of singulating ellipsoid-shaped seeds, but it could not singulate irregular shaped seeds. Chen et al., 1993 developed a multipurpose vacuum seed planter for vegetable crops that suitable for both flat and spherical seeds. They reported that a multipurpose vacuum seed planter was 36 times faster than manual planting. Zigmanov,1997 studied the efficiency of machine sowing of vegetable seeds into containers for 18 vegetable crops and concluded that the factors affecting the efficiency of sowing were the degree of vacuum, nozzle diameter, the method of inserting the nozzle into the vessel holding the seed, the shape of the seed as well as the 
degree of seed finishing, such as cleanliness, sizing, surface polishing and prilling. Kim et al., 2003 developed a vacuum nozzle seeder for the automatic sowing of large seeds of fruit, vegetables and rootstocks. They reported that the important operating factors for obtaining high seeding rates were typically nozzle diameter and extraction vacuum pressure. Sriwongras and Dostal, 2013 used a plug tray for testing 60 cells per one tray. The dimensions of developed machine were 1,044 mm (width), $679 \mathrm{~mm}$ (length), 1,348 mm (height). The important components of the machine consisted of seed hopper, seed metering device, seed releasing unit, soil compressing units and depth controlling units. The metering device was established by plastic sheet. The plastic rod cut into groove along its axis for keeping seeds were inserted into the seed metering device in order to move the seeds from the seed hopper to the flexible tube. The flexible tube brought the seeds into seed releasing units located under the part of seed metering device in order to drop the seeds 1-2 seeds per cell of plug tray. Chain drive mechanism was set to drive the system for releasing seeds on plug tray. Testing the efficiency of releasing seed on plug tray of machine was equal to $79 \%$. For operation time of sowing in plug tray, comparing between this seeder and humanhand showed that the sowing by the seeder was 7.88 times quicker than sowing by human-hand.

Gaikwad et al., 2007 indicated that in vertical vacuum disc seeder, the precision seeding in nursery plug trays requires placement of single seed in each cell. In mechanical seeding, this requirement can be met by vacuum singulation of seeds and dropping one seed in individual cells. Studies were conducted to determine optimum combination of suction pressure and nozzle size for the singulated picking up of tomato and capsicum seeds. Sixteen combinations of different nozzle sizes and suction pressures were evaluated for singulation and seeding of these seeds in plug trays. The suction pressure was found to influence picking up of single seed the most followed by nozzle size for both, capsicum and tomato seeds. The optimum combination of suction pressure and nozzle hole size for more than $90 \%$ singles in the case of capsicum was $(4.91 \mathrm{kPa})$ and $0.49 \mathrm{~mm}$ and for tomato it was $(3.92 \mathrm{kPa})$ and $0.46 \mathrm{~mm}$, respectively. EL-Ghobashy et al., 2016 developed a continuous feeding 
mechanism for precision vacuum trays seeder The developed seeder was evaluated under two trays types of 84 and 209 cells, four different suction pressure levels $(0.5,1,1.5$ and $2 \mathrm{kPa}) \&(0.3,0.6,0.9$ and $1.2 \mathrm{kPa})$ and four different hole size diameters of seed plate $(1.2,1.4,1.6,1.8 \mathrm{~mm}) \&$ $(0.4,0.6,0.8,1.0 \mathrm{~mm})$ for cucumber and cabbage seeds respectively. It was found that the trays seeder productivity was 240 trays $^{-1}$ (20160 and 50160 cells h$^{-1}$ for cucumber and cabbage seeds respectively). The proper seeder results for seeding single seeds in trays (90.5 and 70.4\%) were obtained with the dual interaction effect between the suction pressure at 1.5 and $0.9 \mathrm{kPa}$ and hole diameter at 1.6 and $0.8 \mathrm{~mm}$ for cucumber and cabbage seeds respectively. The consumed specific energy was $4.16 \times 10^{-3}$ $\mathrm{kWh} /$ tray $^{-1}$. Tawfik, 2014 designed, constructed and tested a prototype for seeding tomatoes seeds in trays. The fundamental basic of the prototype was depending on using air vacuum to catch single seed from seed tank and put it inside tray cells using electrical control unit. Engineering parameters were evaluated by analyzing the relative relationships between various parameters such as feeding device height "h, mm" of $0.0,1.0,2.0,3.0$ and $4.0 \mathrm{~mm}$; four different levels of orifice positions "hb" of 1, 2, 3 and 4; four orifice diameters on seeding tube of $0.5,0.75,1.0$ and $1.5 \mathrm{~mm}$ and three air suction pressure " $\mathrm{p}$ " of 3.180, 3.344 and $8.510 \mathrm{kPa}$ on seed catching, doubling and skipping seeds in tray cells. The results reveled that the best value of feeding device height that fulfill catching one seed per orifice was $\mathrm{h}=2.2 \mathrm{~mm}$ at suction tube orifice diameter of $0.5 \mathrm{~mm}$ and air suction pressure of $3.344 \mathrm{kPa}$. Increasing the orifice diameter to $0.75,1.0$ and $1.5 \mathrm{~mm}$ the best (h) were $2.9,3.2$ and $3.9 \mathrm{~mm}$ respectively. At these operating parameters the results recorded no seeds skipping and low doubling. Zhao et al., 2010 investigated the performance of a vacuum-cylinder seeder for the precision sowing of rape seeds. For releasing seeds from nozzles smoothly, a positive differential pressure was applied to the seed. The forces acting on the seeds in free flight were calculated using the computational fluid dynamics (CFD) software Fluent. Using the differential equation for seed motion, seeds falling trajectories using different working parameters were numerically determined. The results indicated that the precision seeding of rape seeds with negative pressure 
were in the range of 1-2 kPa. Gaikwad and Sirohi, 2008 designed and manufactured a prototype pneumatic seeder tested for its performance for sowing capsicum and tomato seeds in plug trays. The seeder could make indents in one row of cells in a plug tray and simultaneously place single seeds in the indented cells. The seeder worked satisfactorily at suction pressures of 4.91 and $3.92 \mathrm{kPa}$ and nozzle diameters of 0.46 and $0.49 \mathrm{~mm}$ to achieve more than $90 \%$ single seed sowing in the case of capsicum and tomato, respectively. The capacity of the seeder, depending on the tray size used and ranged between 38,000 and 60,000 cells $\mathrm{h}^{-1}$. The labor cost with a daily wage of (US\$2.16) per person for sowing seeds manually was found to be (US\$0.22) per 1000 cells. The total cost of sowing 1000 cells with a precision plug seeder was found to be (US\$0.034) which is only $15.27 \%$ of the cost of manual sowing. Thus, a total saving of (US\$0.187) per 1000 cells sown could be achieved for a sowing operation using a precision plug seeder. It was considered that the nursery grower would balance the initial machine cost of (US\$476) with 69.6h of operation of a precision plug seeder having a seeding capacity of 38,800 cells h $^{-1}$.

The objective of this study was to develop a portable compact precision plug tray seeder distinguish of high productivity, able to plant fine and large seeds as well, low cost and has a high singulation efficiency. The machine may fitful farmers requirements especially seed singulation and planting Cucurbits and Solanaceae families seeds with high precision performance.

\section{MATERIALS AND METHODS}

The machine was manufactured in the Agricultural Engineering Research Institute (AEnRI) workshop. The main part of the machine was the seeding unit. It was depended upon a negative pressure passed in small brass nozzle tube with a diameter suitable for the seed mass. Two sets of changeable nozzles holder with 84 or 209 nozzles could be selected to suit the type of the planted seeds. The nozzles holder was fixed underneath the seeding wagon that moved on a track to reach a vibrating tray seeds equipped with grooves contained the seeds. When the wagon reached the left dead point, it was touched a micro-switch operating a 
vibrator underneath the tray seed. Each nozzle pick up one seed and the operator move the seeding wagon towards the nursery tray. At the right dead end of the track, a mechanical shut down valve close the negative pressure from the seeding wagon. Then, a connector arm touches an electrical micro-switch to shut down the blower and open the pneumatic solenoid valve to pass a small quantity of positive air generated by the blower fan inertia inside the air chamber of the seed wagon. At this point, the seed drop from the nozzles into the opposite cells in the foamy seedling tray.

The developed machine was constructed from five sub-units as follows:-

\section{1- Main frame:}

The frame was made from square hallow aluminum section of $(40 \mathrm{~mm}$ $\times 40 \mathrm{~mm} \times 2 \mathrm{~mm}$ thickness). The parts were fitting to each other by plastic fitting with right angle in three dimensions. The total dimension of the frame was (980 mm long, $780 \mathrm{~mm}$ wide and $600 \mathrm{~mm}$ high). The frame was equipped with two aluminum angles $(30 \mathrm{~mm} \times 30 \mathrm{~mm} \times 2 \mathrm{~mm}$ thickness) fixed along the frame to form a seeding wagon track. The frame was consists of two portions, the right portion contained a holder for foam tray, on the other hand the left portion contained the vibrating seeds tray mechanism equipped with four tensional spiral springs to allow the seeding wagon to move vertically to reach the seeds in the tray. When the seeding wagon reaches the left dead point, the operator begins to press the wagon down to make the nozzles enter into the grooves that contains the seeds.

\section{2- Seeding wagon and Nozzles:}

The common dimensions of the trays in Egypt is $(670 \mathrm{~mm}$ long $\times 390 \mathrm{~mm}$ wide $\times 60 \mathrm{~mm}$ high) the same dimensions contained 84 cell for Cucurbits or 209 cell for Solanaceae with different plug dimensions. The seeding wagon was designed and manufactured to meet the dimensions of the tray. It took a box shape made of galvanized steel sheet with thickness of $0.8 \mathrm{~mm}$ and dimensions of $(665 \mathrm{~mm}$ long $\times 410 \mathrm{~mm}$ wide $\times 100 \mathrm{~mm}$ high).The lower edge of the wagon had a right angle rectangle flange to fix the nozzle carrier via bolts and nuts. A rubber gasket was fixed between the wagon rectangle flange and the nozzles carrier to prevent the air leakage. Two types of nozzles carrier were made of galvanized steel 1 
$\mathrm{mm}$ thickness. The first was equipped with 84 nozzles for Cucurbits trays and the second was equipped with 209 nozzles for Solanaceae. The nozzles were made of copper pipes with length of $40 \mathrm{~mm}$ and tined in the nozzle carrier. Four teflon wheels with radius of $35 \mathrm{~mm}$ and $10 \mathrm{~mm}$ thickness were fitted with shafts on both width sides of the wagon and rolls on the track wagon. Fig. (1) shows the seeding wagon and its components.

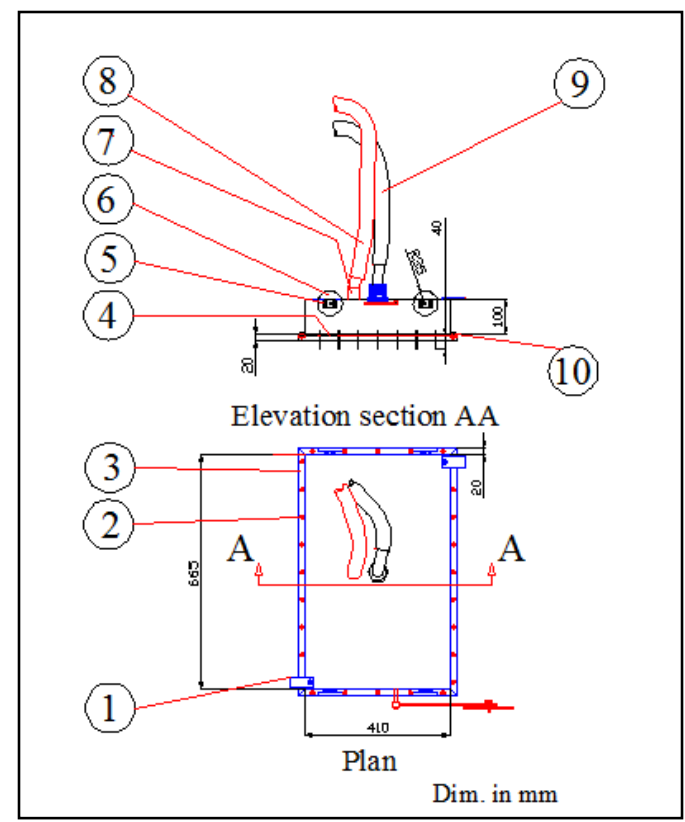

Fig. (1): Seeding wagon components

(1) Micro-switch connector arm,(2)Seeding wagon lock bolts,(3) Seeding wagon flange, (4) Nozzles holder,(5) Wheel axis, (6) Teflon Wheel,

(7) solenoid pneumatic valve,(8) Positive air hose, (9) Negative air hose ,(10) Rubber gasket

\section{Nozzles:}

The nozzles were made of copper tubes with length of $40 \mathrm{~mm}$. The tubes were welded to the nozzles holder by tin. Two types of nozzles were used, the first type for the large seeds with outer diameter of $(2 \mathrm{~mm}$ or more) and inner diameter of (1 $1 \mathrm{~mm}$ or less). The second nozzles were modified to be suitable for fine seeds with outer diameter of $(2 \mathrm{~mm})$ and re-tin to inner diameter of (1.0 $\mathrm{mm}$ or less) to catch only fine seeds. Fig. (2) A and B shows the two types of nozzles. 


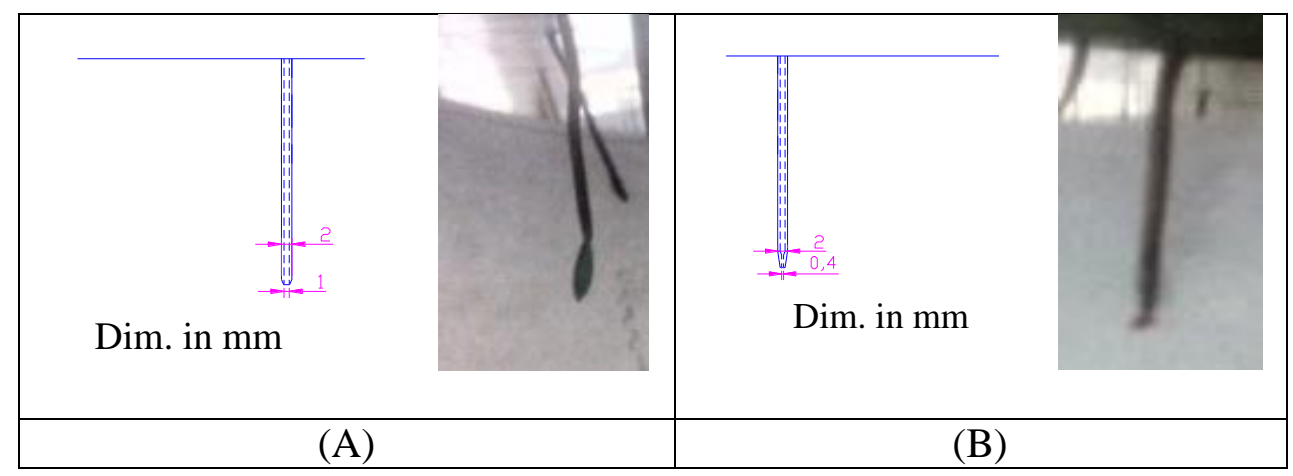

Fig. (2): Types of nozzles

A: Nozzle for large seeds B: Nozzle for fine seeds

\section{Nozzles design parameters:}

Determining the nozzles diameter:

Some physical properties were determined for tomato and cantaloupemelon seeds to assess the nozzle diameter. The calculated results are tabulated in Table (1) using the following:

Geometric mean diameter $\left(D_{g}\right)$ : was calculated according to Singh et al., 2005:-

$$
D_{g}=(L W T)^{1 / 3}
$$

Sphericity $(\varphi)$ of the seeds is calculated according to Abalone et al., 2004:-

$$
\varphi=\frac{D_{g}}{L}=\frac{(L W T)^{1 / 3}}{L}
$$

The nozzles diameter was determined according to Singh, et al., 2005 considered the opening nozzle diameter $\left(d_{o}\right)$ is less than or equal $50 \%$ of size of the geometric mean diameter of the seed $\left(d_{o} \leq 50 \% D_{g}\right)$. The geometric mean diameters of seeds are $D_{g}=1.45 \mathrm{~mm}$ for tomato and $4.23 \mathrm{~mm}$ for cantaloupe-melon (Table 2), Thus:

$d_{o} \leq 0.50 \times \mathrm{D}_{\mathrm{g}}$ and $d_{o} \leq 0.50 \times 1.45 \mathrm{~mm}$. Then $d_{o} \leq 0.73 \mathrm{~mm}$ for tomato. $d_{o} \leq 0.50 \times \mathrm{D}_{\mathrm{g}}$ and $d_{o} \leq 0.50 \times 4.23 \mathrm{~mm}$. Then $d_{o} \leq 2.12 \mathrm{~mm}$ for cantaloupe-melon. 
Table (1): Physical properties of cantaloupe-melon and tomato seeds

\begin{tabular}{|l|c|c|c|c|c|c|}
\hline \multirow{2}{*}{\multicolumn{1}{c|}{ Properties }} & \multicolumn{6}{|c|}{ Seeds types } \\
\cline { 2 - 7 } & \multicolumn{4}{|c|}{ Tomato } & \multicolumn{3}{c|}{ Cantaloupe-melon } \\
\cline { 2 - 7 } & Average & SD & CV & Average & SD & CV \\
\hline Length, $L,(\mathrm{~mm})$ & 2.63 & \pm 0.26 & 9.73 & 8.82 & \pm 0.35 & 3.91 \\
\hline Width, $W,(\mathrm{~mm})$ & 1.83 & \pm 0.18 & 9.95 & 4.61 & \pm 0.23 & 4.95 \\
\hline Thickness, $T,(\mathrm{~mm})$ & 0.64 & \pm 0.08 & 12.09 & 1.86 & \pm 0.06 & 3.34 \\
\hline $\begin{array}{l}\text { Geometric mean diameter, } D_{g}, \\
\text { (mm) }\end{array}$ & 1.45 & \pm 0.12 & 7.98 & 4.23 & \pm 0.11 & 2.58 \\
\hline Sphericity, $\varphi,($ decimal) & 0.55 & \pm 4.32 & 7.79 & 0.47 & \pm 1.17 & 2.44 \\
\hline One thousand seeds mass, $(\mathrm{g})$ & 1.98 & \pm 0.05 & 2.54 & 10.19 & \pm 0.20 & 1.98 \\
\hline
\end{tabular}

SD: Standard division CV: Coefficient of variation

To prevent the seed from entering the seed opening (hole), angle of edges openings on the nozzle should be conical shape to avoid multiple seeds picked up by the nozzle Singh et al., 2005. According to Bakhtiari, 2012 and Singh et al., 2005, the most suitable conical angle of the nozzle is $120^{\circ}$.

\section{3-The vibrating seeds tray:}

The vibrating seeds tray was made of plywood cover with polymer coating. Numbers of conical grooves were made to accomidate the seeds (84 or 209 grooves). The outer side of the tray has a wood edge to prevent the seed fallen. The tray was fixed on a rectangle frame made of angle aluminum section ( $40 \mathrm{~mm} \times 40 \mathrm{~mm} \times 2 \mathrm{~mm}$ thickness). It was assigned to change the vibrating seeds tray and nozzles holder according to the type of the seed. An electrical motor $220 \mathrm{~V}, 3000 \mathrm{rpm}$ equipped with eccentric weight was fitted underneath the frame to spread the seeds in the grooves constantly.

\section{4-The pneumatic system:}

The machine contains two pneumatic systems. A negative pressure was used to catch the seeds into the seeding nozzles and positive pressure used to reject the seed into the tray plugs.

A vacuum blower (equipped with electrical motor $220 \mathrm{~V}, 1.2 \mathrm{~kW}$ and rotor blade speed of $2500 \mathrm{rpm}$ ) was used to generate a negative pressure flowed to the seeding wagon air chamber via a group of pipes and fitting. 
A main air inlet valve was controlled the negative pressure. An innovative pneumatic mechanical valve was also used to make sudden air shut down from the seeding chamber. The valve consisted of a flexible iron sheet articulating on a $6 \mathrm{~mm}$ diameter steel rod to control the inlet of the air flow in the seeding wagon air chamber. A plastic wheel with diameter of $140 \mathrm{~mm}$ was rolled on the same track of the seeding wagon and was adjusted to drop when the seeding wagon reached the dead end of its right travel. Also, a pneumatic solenoid valve was used to control the positive pressure flow inside the air chamber of the seeding wagon. The solenoid valve open when the seeding wagon reached the right dead point, seeding wagon arm touched the right micro switch, and allowed the positive air to enter the air chamber. Fig. (3-A, B, C) show the components of the mechanical pneumatic valve.

\begin{tabular}{|l|l|}
\hline A:Mechancal valve opened & B: Mechanical valve closed \\
\hline C:Mechanical shut down wheel & D: Solenoid pneumatic valve \\
\hline
\end{tabular}

Fig. (3): Mechanical and pneumatic solenoid valves. 
On the other hand, from the outlet of the suction blower the positive air was used to refill the air chamber of the seeding wagon when a sudden air shut down made by the mechanical valve and stop the blower. The internal force in the blower blade was used to generate small positive pressure sufficient to reject the fine seeds from the seeding wagon. Fig. (4): shows a diagram for the pneumatic circuit and its components.

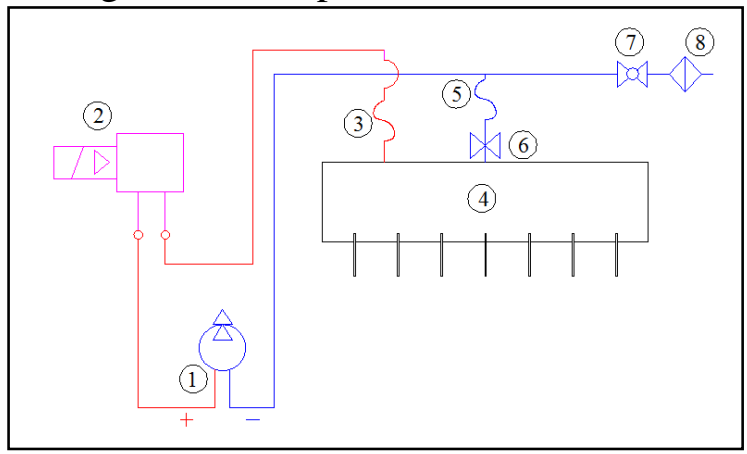

Fig. (4): Diagram for the pneumatic circuit and its components (1) Vacuum pump, (2) Solenoid valve, (3) Positive pneumatic flexible hose, (4) Air chamber, (5) Negative pneumatic flexible hose, (6) Gated valve, (7) Ball valve, (8) Air filter.

\section{5- Control and electrical systems:}

A control box was fitted underneath the planted tray holder contained the main (on/off) power switch and all electrical connections between the electrical parts. Fig. (5) shows the electrical circuit of the developed machine.

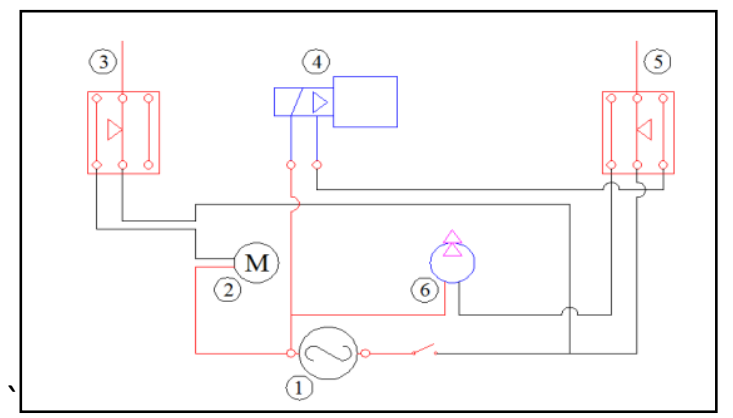

Fig. (5): Diagram of the electrical circuit and its components.

(1) AC Current, (2) Vibration system motor,

(3) One position micro-switch,(4) Solenoid valve,

(5) Two position micro-switch, (6) Vacuum pump. 
Fig.(6) shows the a schematic diagram of the developed machine and its components. Also, Fig.(7) shows an Image of the manufactured machine.

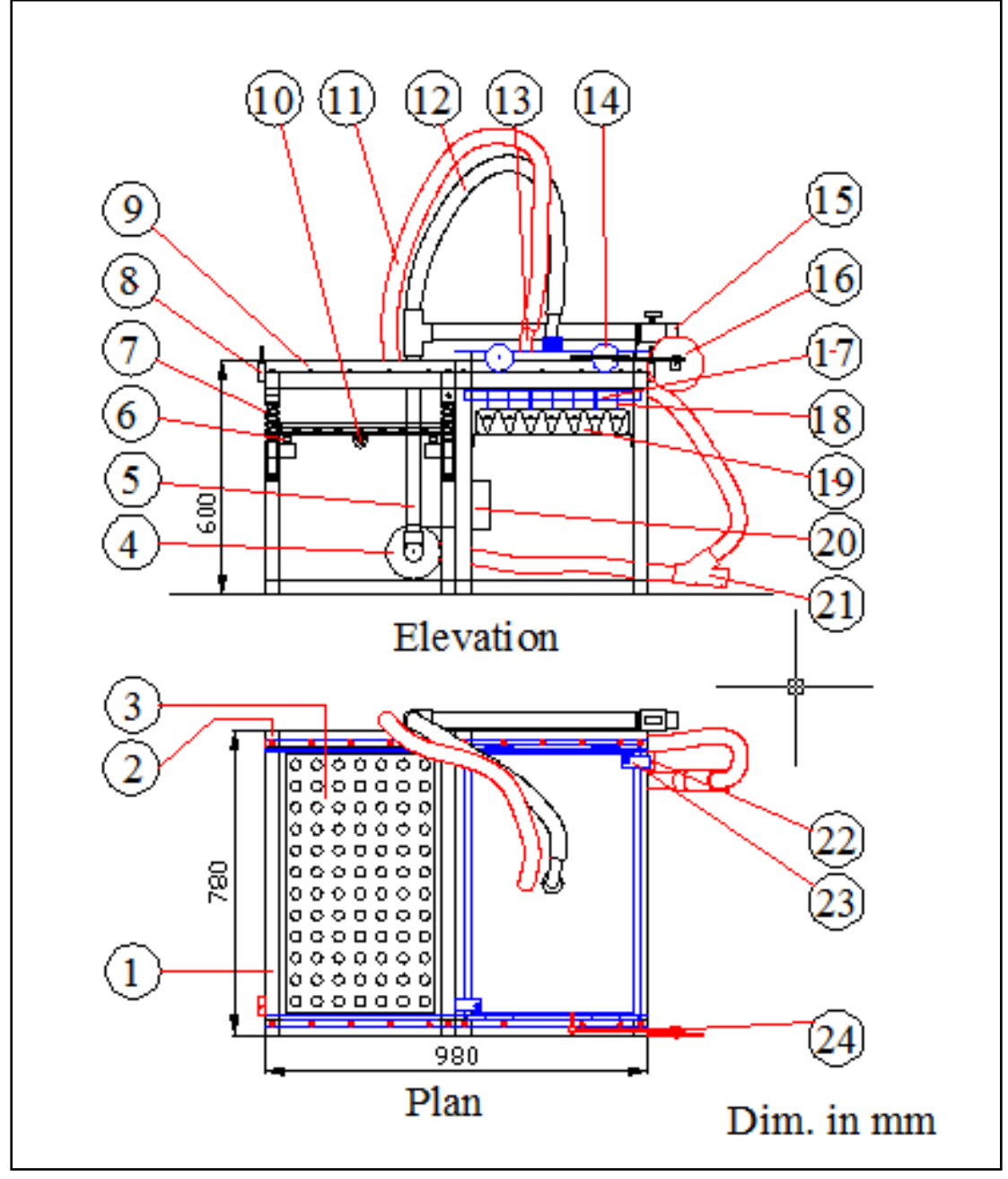

Fig. (6): Schematic diagram of the developed machine

(1) Main frame, (2) Three dimensions plastic fitting,(3) Vibration seeds tray,(4) Suction blower,(5) Main negative air pressure pipe,(6) Rubber shock absorber, (7) Spring, (8) Micro-switch,(9) Seeding wagon track ,(10) Electric vibrator, (11) Positive air pressure hose, (12) Negative air pressure hose,(13) Air solenoid valve, (14) Wagon wheel,(15) Air inlet valve,(16) Mechanical valve wheel,(17) Seeding wagon, (18) Seeding nozzle,(19) Nursery tray,(20) Control box,(21) Angle joint 45 ${ }^{\circ}$, (22) Micro switch, (23) Micro-switch connector arm (24) Mechanical valve adjustment. 


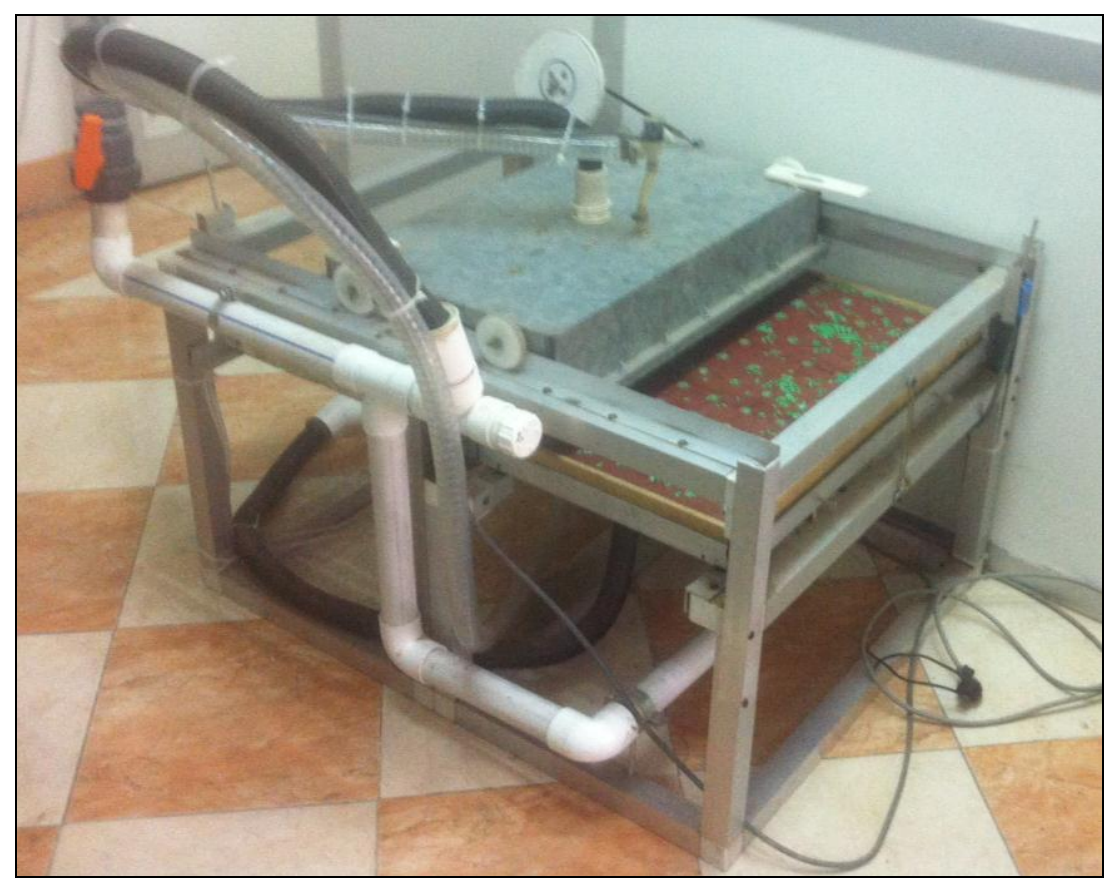

Fig. (7): An Image for the tray plug seeding machine.

\section{Machine operation:}

Table (2) shows the sequence steps of operating of the machine

Table (2): Sequence operating steps of the seeding machine

\begin{tabular}{|c|c|c|}
\hline 1 & $\begin{array}{l}\text {-The foam tray filled with media and put in } \\
\text { tray shelf. } \\
\text { - The micro switch (B) connected the current } \\
\text { to vacuum causing negative pressure in the } \\
\text { seeding wagon air chamber while the } \\
\text { mechanical valve was opened where, the } \\
\text { mechanical valve wheel is on its track } \\
\text { position. } \\
\text {-The operator moved the seeding wagon } \\
\text { towards the seed vibratory tray till the dead } \\
\text { point in (A).then the same micro-switch in } \\
\text { position (B) cut shut down the positive air } \\
\text { via closing the pneumatic solenoid valve. }\end{array}$ & A \\
\hline
\end{tabular}




\begin{tabular}{|l|l|}
\hline & -The micro-switch (A) connected the \\
vibration system underneath the seeding tray \\
operated. \\
-The operator pushed the seed wagon from \\
position (A) to position (C) towards the \\
vibratory seed tray, then the nozzles set to \\
catch seeds. \\
\hline 3
\end{tabular} \begin{tabular}{l}
-The operator moved the seeding wagon \\
from position (A) to position (B). \\
- The micro switch in position (A) shut \\
down the vibratory system. \\
\hline $4 \begin{array}{l}\text { - When the seeding wagon reached the dead } \\
\text { point of position (B), the micro-switch (B) } \\
\text { connect the current to the solenoid valve to } \\
\text { open the positive pressure into the air } \\
\text { chamber and shutdown the suction blower. } \\
\text { In the same time the seeding wagon } \\
\text { mechanical valve completely dropped from } \\
\text { its track shutting down the negative } \\
\text { pressure. Then the seeds drop from the } \\
\text { nozzles into the cells of the tray. }\end{array}$ \\
\hline
\end{tabular}

\section{Measuring instruments:-}

1-Balance: to measure the mass of seeds (accuracy of $0.01 \mathrm{~g}$ ).

2-Digital vernier caliper: to measure seeds principal dimensions, length (L), width (W) and thickness (T). Samples of 100 seeds were randomly selected and the principal dimensions were measured (accuracy of 0.01 $\mathrm{mm})$.

3-Stopwatch: to record the consumed time during calculation of productivity of different treatments.

4-Negative pressure gage (manometer): (from 0 to -100 millibar) (accuracy of 1 millibar) to measure the negative pressure on the nozzle. $(10$ millibar $=1 \mathrm{kPa})$

5-Digital clamp ampere meter: to measure the resistance loaded and unloaded (accuracy of $0.01 \mathrm{~A}$ ). 


\section{Testing procedure:-}

The experiments were carried out in the Agricultural Engineering Research Institute (AEnRI), Dokki .Tomato seeds variety of (Supermarmande) and cantaloupe-melon seeds variety of (Galia melon) were used for the experimental work. Both varieties were treated with antifungi that gave them a notice color could be observed during treatments. The germination percentage was measured for both varieties in Petri plates. The average germination percentage was $88 \%$ for tomato and $92 \%$ for cantaloupe-melon seeds. The machine planted the tomato seeds in 209 cells trays meanwhile, the cantaloupe-melon seeds were planted in 84 cells trays after changing the nozzles holder. Following any treatment the trays were nursed and emergence was measured to find the effect of the machine on seeds.

\section{Experimental treatments:-}

The following treatments were studied to evaluate the parameters affecting on the performance of the developed machine:

(1) Nozzles diameter: four nozzles holders equipped with 84 nozzles inner diameters of $0.76 \mathrm{~mm}, 1.00 \mathrm{~mm}, 1.2 \mathrm{~mm}$ and $1.4 \mathrm{~mm}$ were assigned to cantaloupe-melon. Also, four nozzles holders equipped with 209 nozzles inner diameters of $0.47 \mathrm{~mm}, 0.62 \mathrm{~mm}, 0.76 \mathrm{~mm}$ and $1 \mathrm{~mm}$ were used for tomato seeds.

(2)Negative pressure: $(1,1.25,1.5$ and $1.75 \mathrm{kPa}$ were used with tomato seeds) also (6, 7, 8 and $9 \mathrm{kPa}$ were used with cantaloupe-melon seeds) $(10$ millibar $=1 \mathrm{kPa})$.

Each nozzle holder was attached to the seeding wagon and the negative pressure was changed.

\section{Measurements and calculations:-}

1-Seeding efficiency:-

The seeding efficiency was determined according to Gaikwad and Sirohi, 2008. The percentages of single seed (singulation), double seeds, multiply seeds and missed seeds were calculated for each planted tray 
before cover coating to the total number of tray cells. Each treatment was repeated three times and the average results were taken.

2-Machine productivity $M_{p}$ : Machine productivity was determined according to Gaikwad and Sirohi, 2008 by calculating the number of planted cells per hour.

3-Power requirement $(\mathrm{P})$ : The total power requirement $(\mathrm{kW})$ for the machine power was calculated from the following equation Chancellor, 1981:

$$
P=\frac{I \times V \times \cos \theta}{1000}
$$

where;

$P=$ Total power requirement for the seeder, $k W$;

$I$ = Current strength, Amperes;

$V=$ Potential difference, Voltage;

$\cos \theta=$ Power factor $=$ constant $=0.85$

4-Specific energy consumption (SEC): -

$S E C, \mathrm{kWh} /$ tray is calculated using the following equation:

$$
S E C=\frac{P(\text { Power }, k W)}{\operatorname{Pr}\left(\text { Productivity }, \text { tray } h^{-1}\right)} \ldots
$$

5- Cost analysis and economical evaluation: -

The cost analysis calculated according to Oida, 1997 was performed in two steps. The first step was to calculate the cost of the materials and fabrication. The second step was to calculate the designed machine operating cost. In order to evaluate the financial viability of the machine, three parameters were computed and were analyzed. These parameters are the machine operating cost, the net present value $(N P V)$ and the payback period $(P B P)$.Also a comparison between manual tray seeding cost and mechanical tray seeding cost was conducted.

These costs include depreciation $(D)$, annual capital interest $(I)$ taxes, housing and insurance $(T H I),(R)$ repair and maintenance, power cost $(F)$, and labor cost $(L)$.

$$
\mathrm{T}_{\mathrm{C}}=\frac{\{[(\mathrm{D})+(\mathrm{I})+(\mathrm{THI})]+[(\mathrm{R})+(\mathrm{F})+(\mathrm{L})]\}}{\mathrm{n}} .
$$




$$
T c=\frac{\left\{\left[\left(\frac{P c-S v}{Y}\right)+\left(\frac{(P c+S v)}{2} \times \frac{i}{100}\right)+(0.02 P c)\right]+\left[\left(\frac{P c \times r_{c}}{Y}\right)+\left(P t \times f_{k W}\right)+\left(N \times L_{c} \times n\right)\right]\right\}}{n} \ldots
$$

where;

$T \quad=$ Total cost, $\mathrm{LE} / \mathrm{h}$;

$P \quad=$ Purchase price, $\mathrm{LE}$;

$S v \quad=$ Salvage value $=5 \%$ from the machine purchase LE;

$i \quad=$ Interest rate $=11 \%$

$r_{c} \quad=$ Coefficient of repair and maintenance $=50 \%$

$Y \quad=$ Machine age $=5$ years

Pt = machine power (measured), $\mathrm{kW} / \mathrm{h}$;

$f \quad=$ Electrical $\mathrm{kW}$ price $=1 \mathrm{~kW}=1 \mathrm{~L} . \mathrm{E}$

$N=$ Number of labors $=3$ labors

$L=$ Labor cost $=70$ L.E day, $\operatorname{day}(7$ hours $)$, LE/h;

$n \quad=$ Annual working hours $=500 \mathrm{~h}, \mathrm{~h} /$ year .

\section{RESULTS AND DISCUSSION}

\section{1-The effect of nozzle diameter and negative pressure on seeding} efficiency of tomato seeds:-

The experiments were carried out to sow tomato seeds in 209 cell plug trays to study the effect of the nozzle diameter and negative pressure on seeding efficiency. The average values of seeding efficiency (\%) were taken for nozzle diameter of $(0.47,0.62,0.76$ and $1.00 \mathrm{~mm})$ by changing the nozzle holders and changing the negative pressure from $1 \mathrm{kPa}$ to $1.25,1.5$ and $1.75 \mathrm{kPa}$ by adjusting the air inlet valve. The treatments were made to determine the optimum calibration of the negative pressure and the optimum nozzle diameter. Seed singulation (\%) was the effective parameter that evaluated the performance of the seeding machine. Fig. (8) shows effect the of nozzle diameter and negative pressure on seeding efficiency of tomato seeds. It is known that, the selection of nozzle diameter and its turn effective pressure depends on the geometric diameter of the tomato seed. By increasing the nozzle diameter from 0.47 to $0.62 \mathrm{~mm}$ the average singulation increased from 81.94 to $85.65 \%$. Meanwhile by increasing the nozzle diameter from $0.47 \mathrm{~mm}$ to $(0.76 \mathrm{~mm}$ and $1.00 \mathrm{~mm}$ ) the average singulation decreased from $81.94 \%$ to $70.93 \%$ and $64.24 \%$ )respectively. From Fig. (8),it was found that the maximum 
seed singulation ratio was $91.39 \%$ at nozzle diameter of $0.62 \mathrm{~mm}$ with negative pressure of $1 \mathrm{kPa}$. Meanwhile, the minimum seed singulation ratio was $55.98 \%$ at nozzle diameter of $1.00 \mathrm{~mm}$ and negative pressure $1.75 \mathrm{kPa}$. At nozzle diameter of $0.47 \mathrm{~mm}$ and negative pressure of $1 \mathrm{kPa}$, it was realized that the seed singulation ratio was approached $83.73 \%$ with decreasing percentages of $(1.13,2.85$, and $4.57 \%)$ at negative pressure of $(1.25,1.5$, and $1.75 \mathrm{kPa})$ respectively. Meanwhile, at the same negative pressure of $1 \mathrm{kPa}$, the ratio of missed seeds was decreased from $14.35 \%$ with decreasing percentage of $(16.66,66.69$, and $83.34 \%)$ at negative pressure of $(1.25,1.5$, and $1.75 \mathrm{kPa})$ respectively. At nozzle diameter of $0.62 \mathrm{~mm}$ and negative pressure of $(1.00,1.25,1.5$, and 1.75 $\mathrm{kPa}$ ), the seed singulation ratio was decreased from $91.39 \%$ with decreasing percentage of $(1.58,8.38$, and15.19\%) respectively. The relation takes the same trend at nozzle diameter of $(0.76$ and $1.00 \mathrm{~mm})$ when increasing the negative pressure from $(1.00 \mathrm{kPa})$ to $(1.25,1.5$, and $1.75 \mathrm{kPa})$ with decreasing ratio of $(2.58,5.80$, and 9.03\%) and (8.00, 12.00 , and $22.00 \%$ ) respectively.

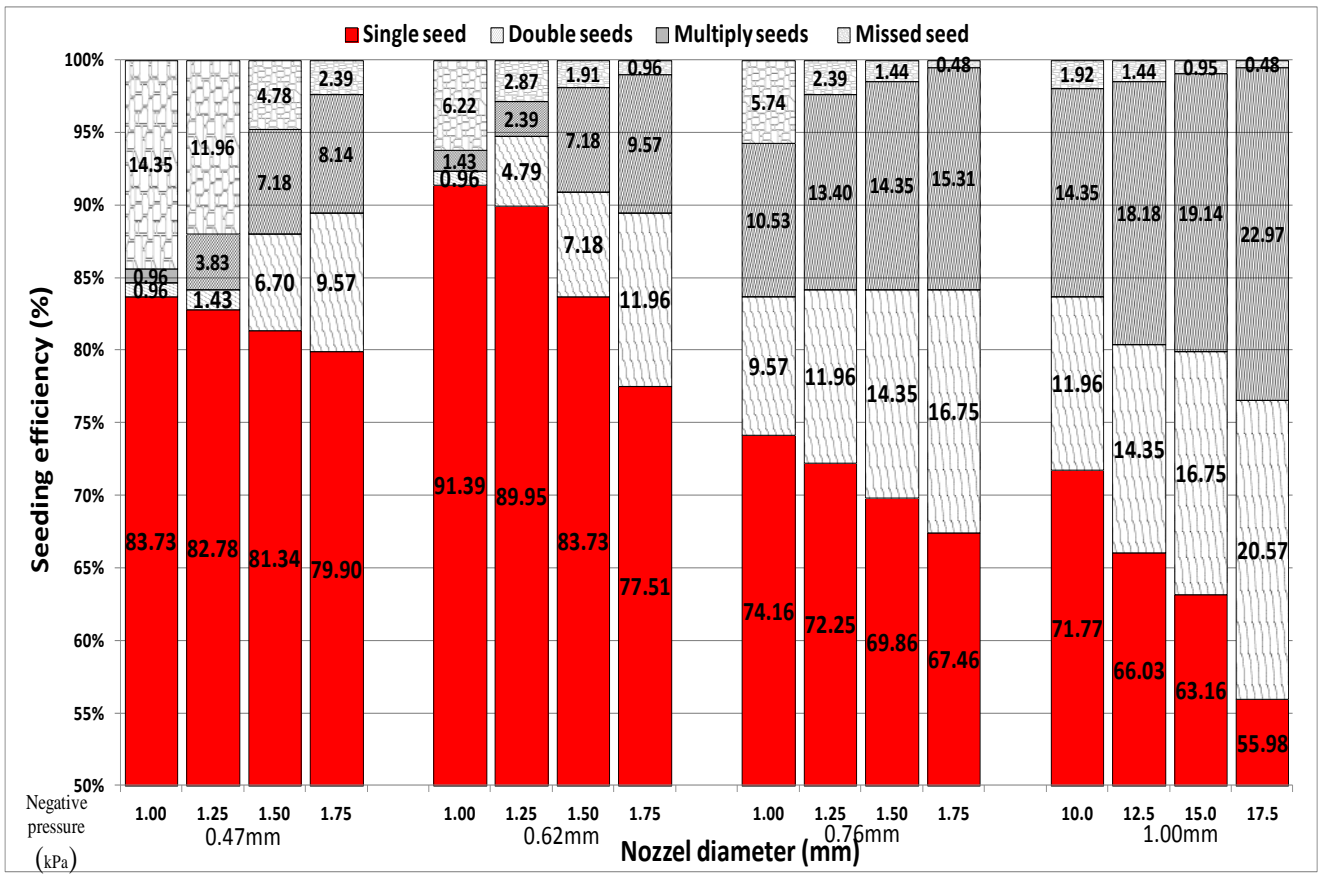

Fig. (8): The effect of nozzle diameter and negative pressure on seeding efficiency of the tomato seeds 
Also, at nozzle diameter of $0.47 \mathrm{~mm}$ and negative pressure of $1 \mathrm{kPa}$ the double seed percentage was increased from $0.96 \%$ with increasing percentage of $(32.87,85.76$, and $89.97 \%)$ at negative pressure of $(1.25$, 1.5 , and $1.75 \mathrm{kPa})$ respectively. At nozzles diameter of $(0.62,0.76$ and $1.00 \mathrm{~mm})$,negative pressure $(1.25,1.5$, and $1.75 \mathrm{kPa})$, the double seed ratio was increased with percentage of $(79.96 \%, 86.63 \%$, and $91.97 \%)$ ,(19.98,33.31, and 42.87\%),(16.66,28.60,and41.86\%) respectively. Meanwhile, at nozzle diameter of $0.47 \mathrm{~mm}$ and negative pressure of 1 $\mathrm{kPa}$ the ratio of multiply seeds ratio was increased with percentage of (74.93 ,86.63 , and 88.21\%),(40.17,80.08, and 85.06\%) ,(21.42,26.62, and $31.22 \%),(21.07,25.03$, and $37.53 \%)$ at nozzles diameter of $(0.62,0.76$ and $1.00 \mathrm{~mm})$ respectively.

From Fig. (8), it realized that the optimum nozzle diameter for planting tomato seeds is $0.62 \mathrm{~mm}$ operated at negative pressure of $1.25 \mathrm{kPa}$ that gave percentage of single seed $89.95 \%$, double seeds $4.79 \%$, multiply seeds $2.39 \%$ and missed seeds $2.87 \%$.

Also, a random sample of the planted trays was nursed to find out the effect of the machine on seeds variability. The average plants emergence percentage was $(\approx 88 \%)$.

\section{2- The effect of nozzle diameter and negative pressure on seeding efficiency of the cantaloupe-melon seeds:-}

The experiments were carried out to plant cantaloupe -melon seeds in 84 cell plug trays to study effect the nozzle diameter and negative pressure on seeding efficiency. The average values of seeding efficiency (\%) were monitored with nozzles diameter of $(0.76,1.00,1.2$ and $1.4 \mathrm{~mm})$ by changing the nozzle holders and changing the negative pressure from( 6.0 $\mathrm{kPa})$ to $(7.0,8.0$ and $9.0 \mathrm{kPa})$ by adjusting the air inlet valve. The treatments were done to determine the optimum calibration of the negative pressure and the optimum nozzle diameter. Fig. (9) shows the effect of nozzle diameter and negative pressure on seeding efficiency of the cantaloupe-melon seeds.

From Fig.(9), it was realized that maximum seed singulation ratio was $94.05 \%$ at nozzle diameter of $1.20 \mathrm{~mm}$ and negative pressure $8.0 \mathrm{kPa}$. 
Meanwhile, the minimum seed singulation ratio was $76.19 \%$ at nozzle diameter of $0.76 \mathrm{~mm}$ and negative pressure $6.0 \mathrm{kPa}$. By increasing the nozzle diameter from 0.76 to $1.00 \mathrm{~mm}$ the average singulation increased from 77.98 to $84.82 \%$. Meanwhile by increasing the nozzle diameter from $0.76 \mathrm{~mm}$ to $(1.20$ and $1.40 \mathrm{~mm})$ the average singulation percentage increase from $77.98 \%$ to $(88.40$ and $86.91 \%)$ respectively.

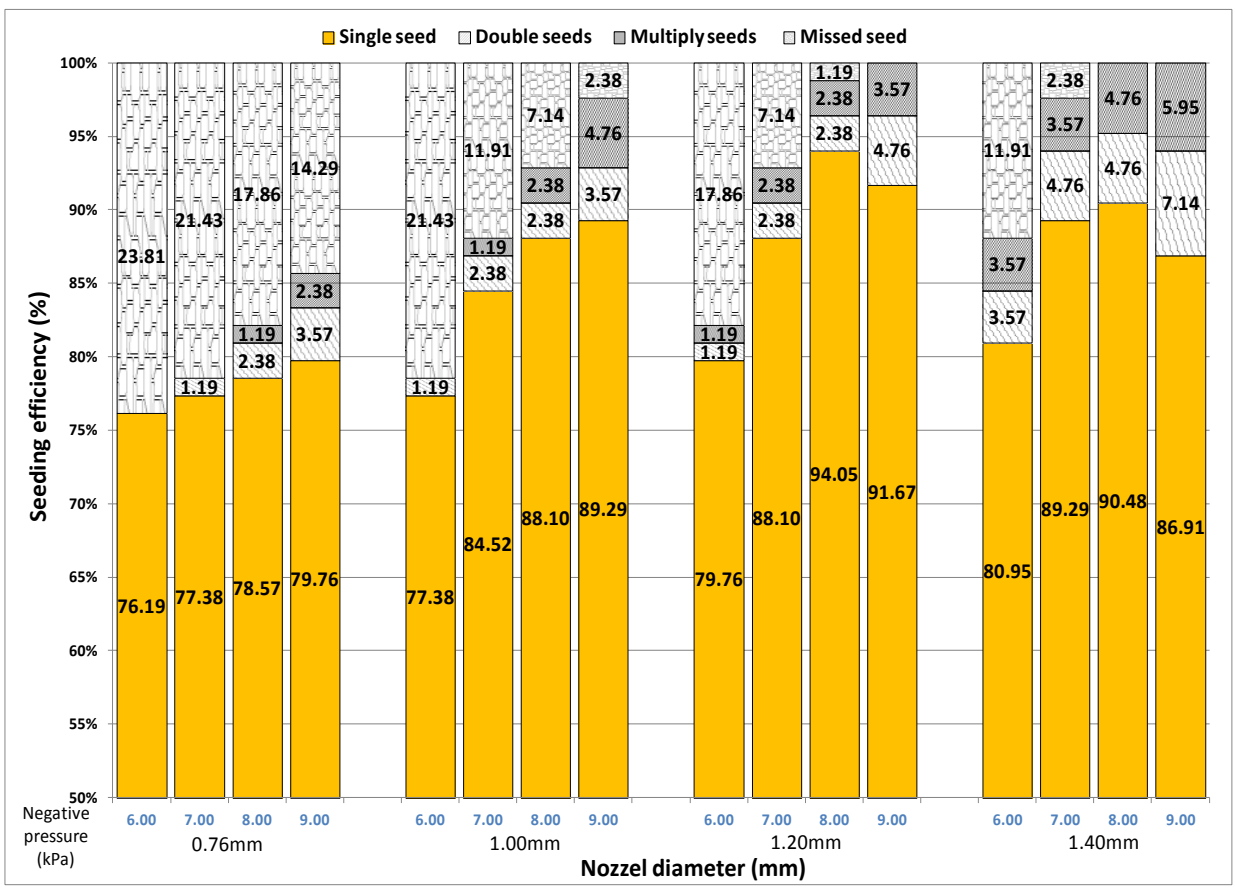

Fig.(9): The effect of nozzle diameter and negative pressure on seeding efficiency of the cantaloupe-melon seeds

At nozzle diameter $0.76 \mathrm{~mm}$, the seed singulation ratio increased from $76.19 \%$ with increasing percentage of $1.54,3.03$, and $4.48 \%$ when increasing the negative pressure from $6.0 \mathrm{kPa}$ to $(7.0,8.0$, and $9.0 \mathrm{kPa})$ respectively. The relation take the same trend at nozzle diameter of $1.00 \mathrm{~mm}$ with increasing percentages of $(8.45,12.17,13.34 \%)$ when increasing the negative pressure from $6.0 \mathrm{kPa}$ to $(7.0,8.0$, and $9.0 \mathrm{kPa})$ respectively.

At negative pressure of $6.0 \mathrm{kPa}$, nozzle diameter of 1.2 and $1.4 \mathrm{~mm}$ the single seed percentage was increased by $(9.47 \%$ and $15.19 \%)$ and $(9.34 \%$ 
and $10.53 \%$ ) respectively when increasing the negative pressure from 6.0 $\mathrm{kPa}$ to $(7.0$ and $8.0 \mathrm{kPa})$. Then, the single seed percentage increased by only (12.99 and $6.86 \%$ ) when increasing the negative pressure to $9.0 \mathrm{kPa}$ respectively.

Also, it was found that the missed seed percentage is increasing by decreasing the negative pressure. The percentage was decreased from 23.81 to $21.43,17.86$ and 14.29 when increasing the negative pressure from $6.0 \mathrm{kPa}$ to $(7.0,8.0$, and $9.0 \mathrm{kPa})$ respectively. The relation was taken the same trend at nozzle diameter $1.00 \mathrm{~mm}$. When the nozzle diameter was increased to $(1.2 \mathrm{~mm}$ and $1.4 \mathrm{~mm})$ with negative pressure of $(8.0$ and $9.0 \mathrm{kPa})$ the percentage of missed seed reached to (Zero\%) but the singulation seed percentage was decreased.

From Fig. (9), it was realized that the optimum nozzle diameter for planting the cantaloupe-melon seeds is $1.20 \mathrm{~mm}$ operated at negative pressure $8.0 \mathrm{kPa}$ that gave percentage of single seed $94.05 \%$, double seeds $2.38 \%$, multiple seeds $2.38 \%$ and missed seeds $1.19 \%$. Also, a random sample of the planted trays was nursed to find out the effect of the machine on seeds variability. The average plants emergence percentage was $(\approx 92 \%)$.

\section{3-Productivity and specific energy consumption:}

The productivity of precision vacuum trays seeder was 320 tray/ $\mathrm{h}$ (66880 and 26880 cells/ h) for tomato and cantaloupe-melon seeds respectively, comparing with 1225 cells/ h for handy seeding (6 and 15 trays/ h for 209 and 84 cells/ tray) (Gaikwad and Sirohi, 2008). This means that the productivity of trays seeder reduced the seeding time by 21 and 53 times than that seeding trays manually for tomato and cantaloupe-melon respectively.

Total power requirement for the seeder was $1.075 \mathrm{kWh}$ for tomato seeds and $1.216 \mathrm{kWh}$ for cantaloupe melon seeds. The consumed specific energy were $\left(3.36 \times 10^{-3} \mathrm{kWh} /\right.$ tray $)$ for tomato seeds and $\left(3.80 \times 10^{-3} \mathrm{kWh} /\right.$ tray) for cantaloupe melon seeds. 


\section{4-Cost analysis and economical evaluation:- Machine operation cost:-}

The calculation of operating costs included fixed and variable costs were made for the seeding machine. The total operating costs for the seeding machine was $43.37 \mathrm{LE} / \mathrm{h}$.

The labor could sow a maximum of 6 tomato trays/h and 15 cantaloupe melon trays/ h. Meanwhile, the machine productivity was 320 tray/h. The labor cost was $10 \mathrm{LE} / \mathrm{h}$; the machine cost was $43.37 \mathrm{LE} / \mathrm{h}$. This mean, the cost of tray seeded by the machine was $0.14 \mathrm{LE} /$ tray comparing with (0.67 and 1.67) LE/try for hand seeding for cantaloupe melon tray and tomato tray respectively.

\section{Economical feasibility of the developed machine:-}

The total fabrication cost of the seeding machine was 5000 LE with 2016 price level. The total operating costs was $35.26 \mathrm{LE} / \mathrm{h}$. The rental value of mechanical seeding per tray was $0.20 \mathrm{LE}$. The seeding machine indicated $(N P V)$ of $2930 \mathrm{LE}$ at $11 \%$ interest rate. The seeding machine payback period $(P B P)$ was about 1.3 year.

\section{SUMMARY AND CONCLUSION}

The obtained results can be summarized as follows:-

1-The machine success to plant large seed and small seed in different types of plug trays. The optimum nozzle diameter for planting the tomato seeds variety of (Super-marmande) was $0.62 \mathrm{~mm}$ operated at negative pressure of $1.25 \mathrm{kPa}$ that gave percentage of single seed $90.0 \%$, double seeds $4.8 \%$, multiply seeds $2.4 \%$ and missed seeds $2.9 \%$. Also, the optimum nozzle diameter for planting the cantaloupe-melon seeds variety of (Galia melon) was $1.20 \mathrm{~mm}$ operated at negative pressure $8.0 \mathrm{kPa}$ that gave percentage of single seed $94.05 \%$, double seeds $2.38 \%$, multiple seeds $2.38 \%$ and missed seeds $1.19 \%$.

2-The seed singulation ratio affected by nozzle diameter and negative pressure value. Both parameters affected by the mass of the seed. Generally, the singulation seed percentage is decreasing by increasing to the nozzle diameter and negative pressure value. 
3- The machine succeeded to decrease the seeding cost.The cost of tray seeded by the machine was $0.14 \mathrm{LE} /$ tray against (0.67 and 1.67) LE/try for hand seeding for (cantaloupe melon tray and tomato tray) respectively.

4- The machine is not affected on the seeds. The germination results indicated that the seedling emergence ratio was the same of the seed germination ratio.

The following conclusions and recommendations can be drawn:-

1-The seeding machine can be manufactured locally with cheap price for small seedling nursery holders.

2-the seeding machine made from light materials $(\approx 18 \mathrm{~kg})$ can be potable from nursery to another to fitful any small holder seedling nursery.

3-Using the machine is surly increase the market value of the mechanically tray seeded due to low ratio of double, multiply and missed seeds.

\section{REFERENCES}

Abalone, R., A.Cassinera, , A.Gastón,, and M. A. Lara. (2004). Some physical properties of amaranth seeds. Biosystems Engineering, 89(1): 109-117. doi: 10.1016 / J. Biosystemseng.

Bakhtiari, M. R. (2012). Design, development and evaluation of a kenaf pneumatic seeding machine. $\mathrm{PhD}$ Thesis, University Putra Malaysia, Kuala Lumpur, Malaysia. Retrieved from http://www.upm.edu.my.

Chancellor, W. J. (1981). Substituting information for energy in agricultural. Trans. ASAE, Paper No. 0001-2351.

Chen, J. M., C. C. Yu, J. H. Lei, J. M. Yu , and C. F. Chang.(1993). A multipurpose vacuum seed planter for vegetable crops plantings. Journal of Agriculture and Forestry, 42(1), 1-18. 
EL-Ghobashy, H. M., T. H. A. Mohamed, A. M. EL-Ashker , and Y. A. Shabaan.(2016).Development of a Locally Vacuum Vegetable Seeder for Nursery TraysJ.Soil Sci. and Agric. Eng., Mansoura Univ., Vol. 7(8): 595- 602.

Gaikwad B.B, N.P.S. Sirohi, and A. Kumar.(2007). Studies on Vacuum Singulation of Seeds for Sowing Nursery Plug Trays. Journal of Agricultural Engineering . Vol.44, 54- 59. Print ISSN : 0256-6524.

Gaikwad B.B. and, N.P.S. Sirohi.( 2008).Design of a low-cost pneumatic seeder for nursery plug trays. Biosystem Engineering. 322 - 329.

Hanacek, W. A. and P. Bickel.(1984). United States Patent. Patent No. $4,466,554$.

Kim, D. E., Y. S. Chang, S. H. Kim, and G. I. Lee.(2003). Development of vacuum nozzle seeder for cucurbitaceous seeds (I)-design factors for vacuum seeding large sized seeds. Journal of the Korean Society for Agricultural Machinery, 28(6), 525-530.

Oida , A. (1997). Using personal computer for agricultural machinery management . Kyoto University. Japan. JICA publishing.

Singh, R. C., G. Singh, and D. C. Saraswat. (2005).Optimization of design and operational parameters of a pneumatic seed metering device for planting cottonseeds. Biosystems Engineering, 92(4): 429-438.

Sriwongras P. and P. Dostal. (2013). Development of seeder for plug tray. MENDELNET . 867-871.

Tawfik, H.A.( 2014). Developing an automatic mechanism for precision seeder. Ph. D. thesis. Agric. Eng. Dept., Agric. Fac. Mansoura Univ.

Zhao Z., L.Yaoming, J. Chen, and X. Lizhang. (2010). Numerical analysis and laboratory testing of seed spacing uniformity 
performance for vacuum-cylinder precision seeder. Biosystems Engineering, 106, 344-351.

Zigmanov, P. (1997). Efficiency of Machine Sowing of Vegetable Seed into Containers. Novi Sad, Yugoslavia. (p 92).

\section{الملخص العربي}

\section{وحدة بذر دقيقة مبتكرة لزراعة صوانى الشتل}

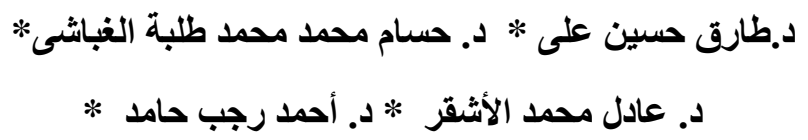

تم تصنيع آلة بذر هوائيه لزراعه صوانى شتل الخضر تتميز بحجمها المدمج ودقتها

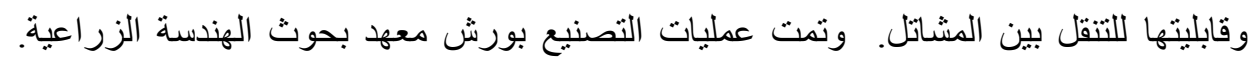

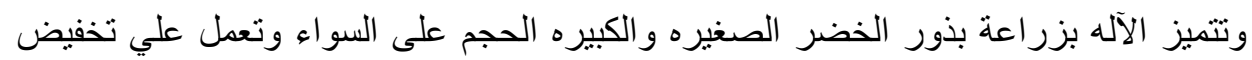

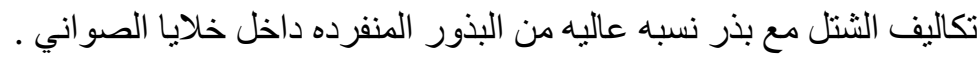

ويعتمد تتغيل الآله على التحكم فى الضغط السالب والموجب حيث يتم التقاط البذور بالضغط

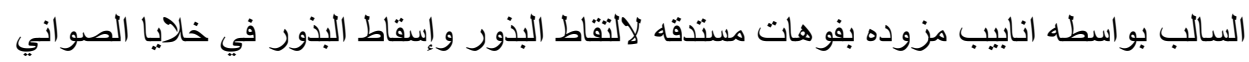

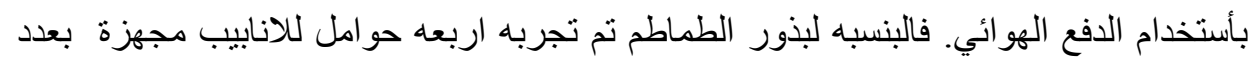

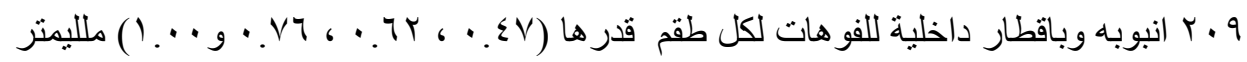

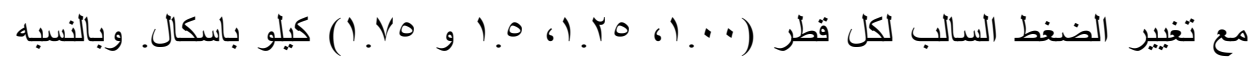

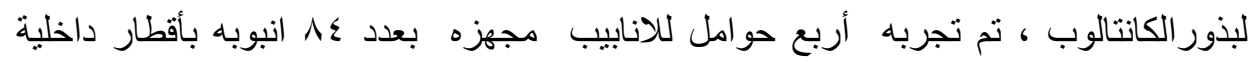

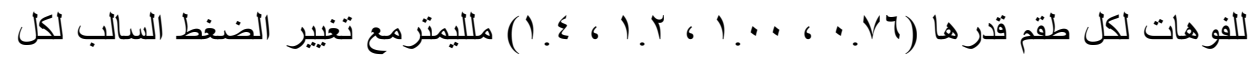

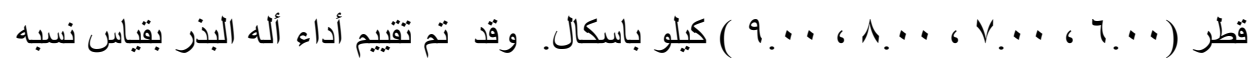

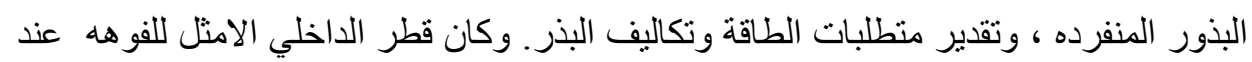

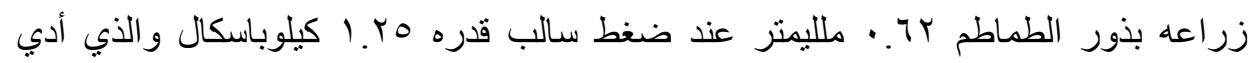

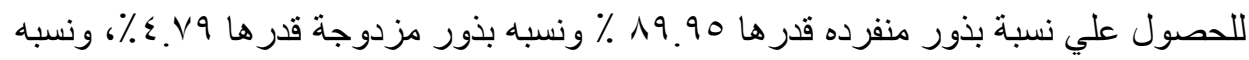

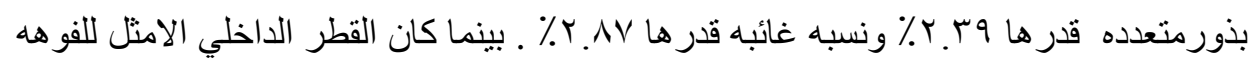

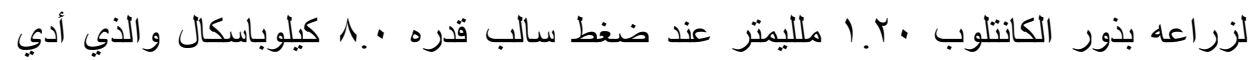

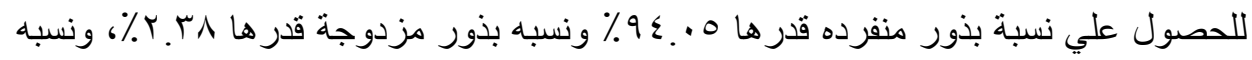

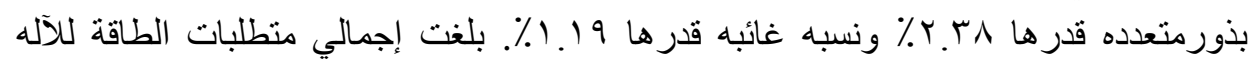

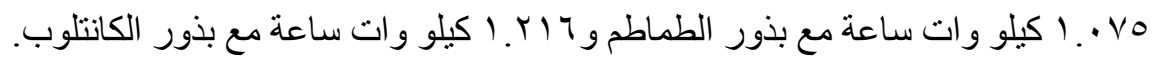

*باحث بمعهد بحوث الهندة الزراعية ـ مركز البحوث الزراعية - وزارة الزراعة ـ الدقي - الجيزة. 


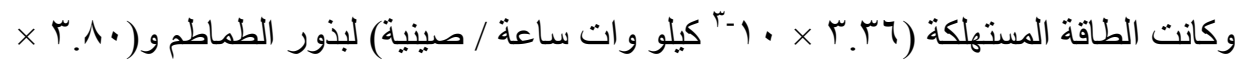

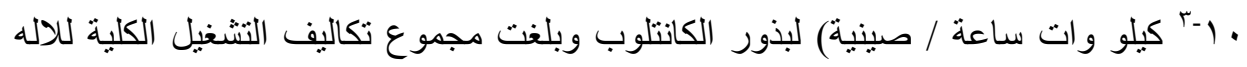

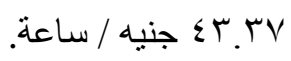

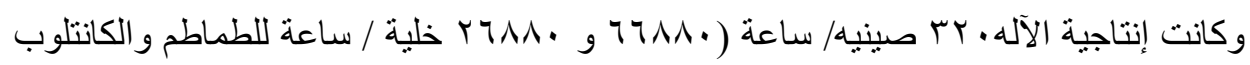

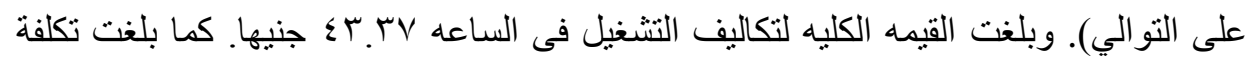

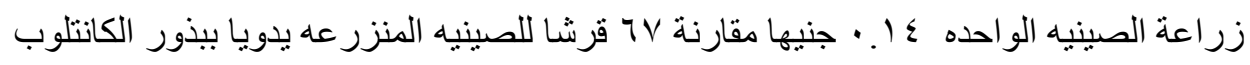

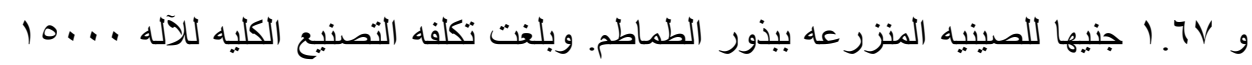

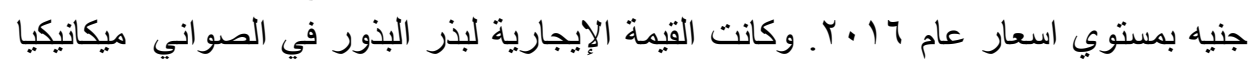

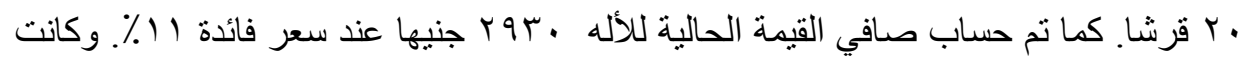

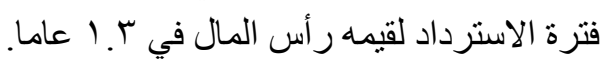

